\title{
Key performance indicators of major companies: a study on Russian metallurgical industry
}

\author{
Daria Baklanovskaya ${ }^{1, *}$, Marat Goguadze ${ }^{2}$ and Alexey Shmatko ${ }^{3}$ \\ ${ }^{1}$ Russian Presidential Academy of National Economy and Public Administration, North-West Institute of Management, 199178 Saint \\ Petersburg, Russia \\ ${ }^{2}$ Baltic State Technical University "VOENMEH" named after D.F. Ustinov, Philosophy Department, 190015 Saint Petersburg, Russia \\ ${ }^{3}$ Baltic State Technical University "VOENMEH" named after D.F. Ustinov, Organization Management Department, 190015 Saint \\ Petersburg, Russia
}

\begin{abstract}
The development of the metallurgical industry requires investing in the environmental safety of processes and technologies of metal processing, as well as to the measures aimed at energy costs reduction. We will look at the economic impact of reducing production costs by saving resources and improving the efficiency of the energy complex. The financial effect of reducing energy consumption per unit of production can be achieved by optimizing the purchase of energy resources, modes of operation of technological and support equipment, improving the management of the company's energy complex. The article examines the most important indicators of the operating and financial activities of the three companies in the steel industry-Novolipetsk and Magnitogorsk Metallurgical Plants, as well as Severstal PJSC. The financial stability of these companies and the agility of their capital are quite high, and their fixed assets are financed by their own funds. Companies are also financially stable in the short term, as evidenced by the high current liquidity ratios ( 2 and above), and their own capital exceeds borrowing by 1.5 to 2 times. Thus, we can conclude that they are operationally efficient and have good financial sustainability in the short and long term.
\end{abstract}

\section{Introduction}

Expansion of production volumes, creation of new technologies in the metallurgical industry involves an increase in the volume of processing of raw materials and, as a result, an increase in emissions of dust and various gaseous substances into the atmosphere. With an increase in production volumes and, correspondingly, an increase in pollution, above the assimilation capacity of the environment, external costs are imposed on the enterprise [8]. We will present the results of financial analysis of three biggest Russian metallurgical companies, Severstal PJSC, Novolipetsk and Magnitogorsk Metallurgical Plants.

\section{Methods}

As key we will consider the following groups of indicators:

1. Business performance;

2. Financial sustainability indicators;

3. Liquidity and solvency indicators.

They will allow us to draw a conclusion about the efficiency of the operating activities of these companies and, if necessary, to adjust it.

Business activity analysis is often referred to as an analysis of the quality of the management of a company
[5]. Some authors propose to make qualitative and quantitative assessment at the same time. A qualitative assessment involves an analysis of reputation, markets, regular customers, quality of products. A quantitative one calls for calculation of various indicators. That is what we will focus on. All the data is obtained from the official websites of the companies $[2,3,4]$.

\subsection{Total return, defined as Sales Revenue/Average Property Value (designated $\mathbf{R}_{\text {TAT) }}$}

This indicator is also called return on assets, or coefficient of return on total assets. It characterizes the efficiency of using all the company's property in relation to the proceeds. The graph shows a fairly significant increase in the indicator for the period under review for all 3 companies. starting from 2017, its value exceeds one, which indicates the comparability of revenue and assets and indicates effective work. But for a deeper analysis of the causes of this phenomenon, additional data is required: it is necessary to compare the accounting policies of companies, accounting for depreciation, overstatement of revenue, and so on.

\footnotetext{
${ }^{*}$ Corresponding author: 1 kshamina@ rambler.ru
} 


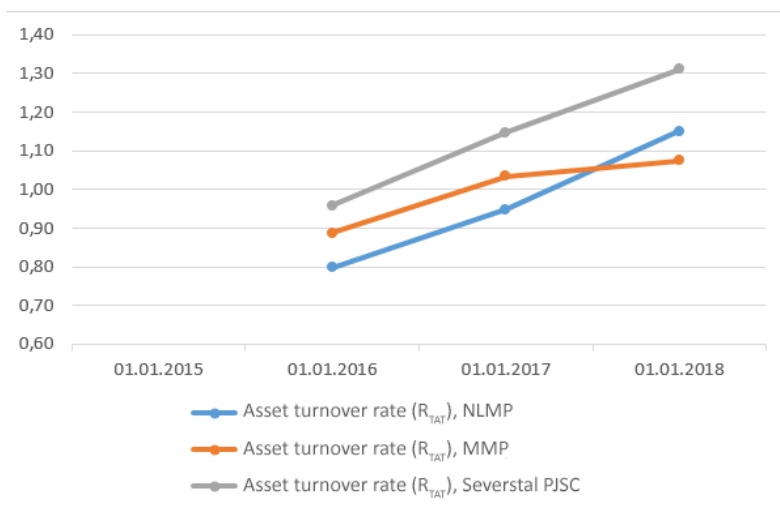

Fig. 1. Asset turnover rates, times.

\subsection{Turnover of fixed assets, defined as Sales Revenue/Average Value of Non-Current Assets ( RAT $_{\text {FAT }}$}

This indicator shows how effectively the company uses its fixed assets (equipment, land, facilities, plantings, intangible assets, etc.).

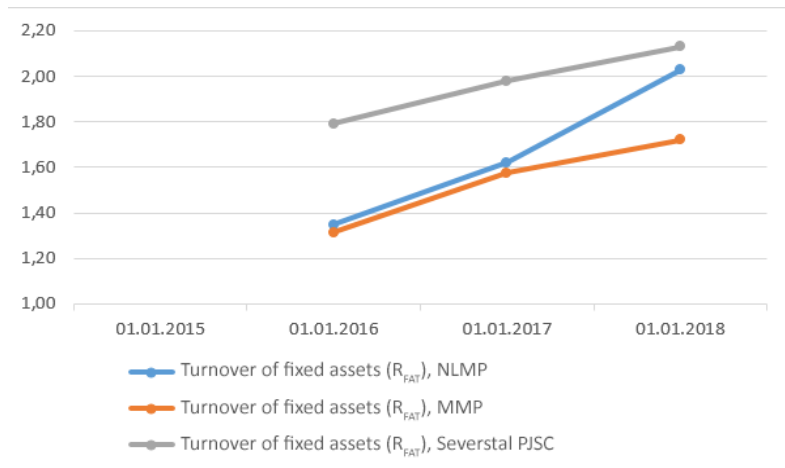

Fig. 2. Turnover of fixed assets, times.

From the graph it is clear that this coefficient is growing for all 3 companies, and NLMP and Severstal have revenues more than twice the fixed assets, i.e. these companies use them more efficiently than the Magnitogorsk plant. This dependency is considered typical for enterprises in asset-intensive industries.

\subsection{Turnover of operating assets, defined as Sales Revenue/Average Operating Value ( $\mathbf{R}_{\text {WCT }}$ )}

This indicator describes the number of turnovers of all operating capital. We believe that the higher this figure, the faster the company's investments in stocks are reimbursed and there is a good demand for its products. This figure can also be defined in days (365/RWCT).

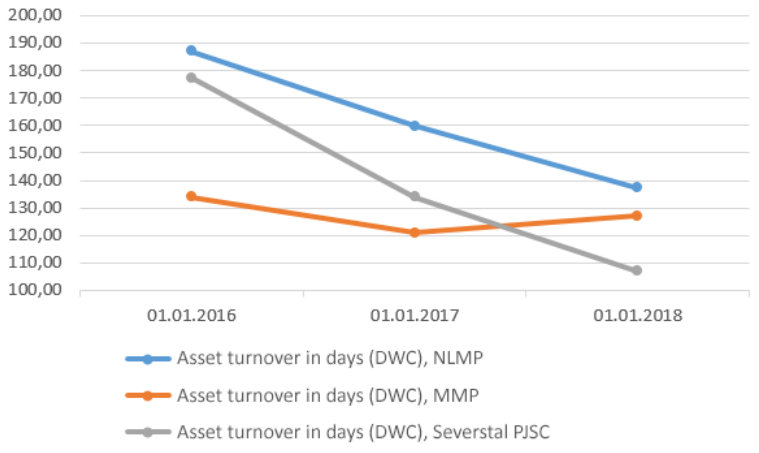

Fig. 3. Asset turnover rate, days.

It is clear from the graph that companies are striving for operational efficiency and the number of days of turnover is greatly reduced, especially at the Novolipetsk plant and Severstal: from 180-190 days to 137 and 106 respectively. Implicitly, this process takes place at the Magnitogorsk plant, where the acceleration is 6 days. For a non-inflationary situation, this may mean working at a minimum of funds, reducing stocks, and making quick sales of products.

The following group of coefficients specifies turnover by category:

\subsubsection{Inventory turnover, defined as 365/(Sales revenue /Average stocks of finished products))}

This indicator allows us to determine the rate of return of frozen funds in stocks.

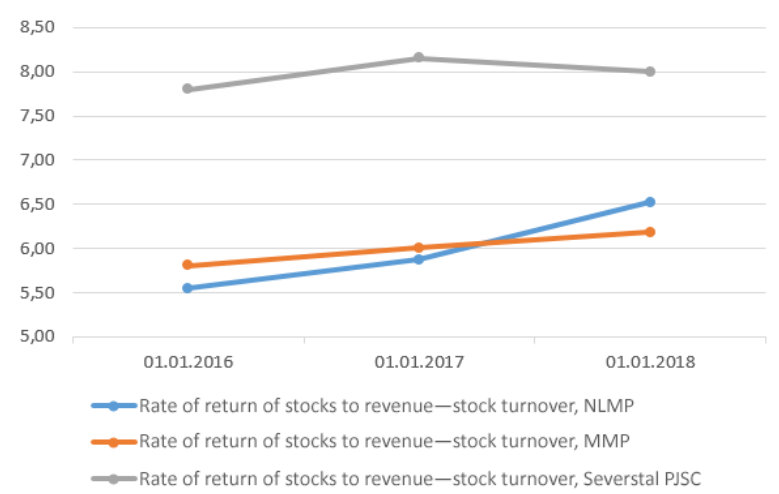

Fig. 4. Stock turnover.

It is clear from the graph that this figure is also growing for all three companies, but Severstal PJSC is leading by a large margin, the value of the company's reserves returns in 45 days in 2018 compared to the rest of the companies, which achieve it over the period of about 55 days.

\subsubsection{Receivable turnover- $R_{A R T}$ is defined as Revenue/Average receivables}

This indicator is important for several reasons: accounts receivable are often a significant share of current assets, and the ratio indicates a company policy with debtors. 


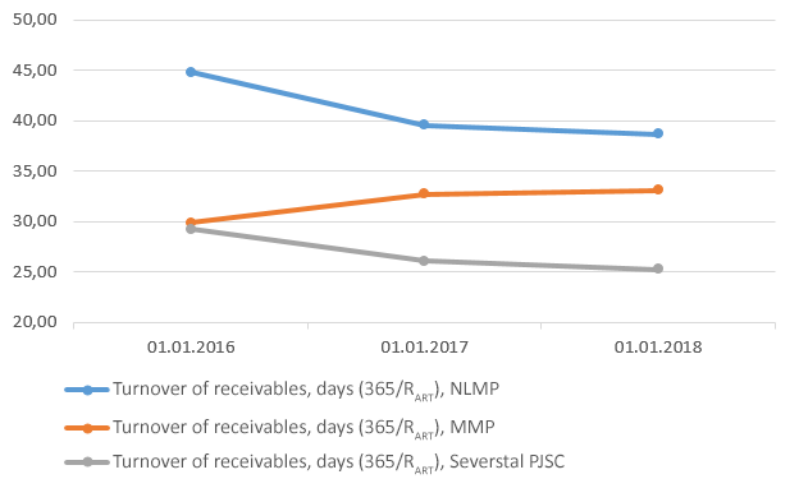

Fig. 5. Turnover of receivables, days.

The decrease in the number of days of receivables turnover is a positive trend and is typical for the Severstal and Novolipetsk plant (for 4 and 6 days). At the same time, this period increased by 4 days at the Magnitogorsk plant. Thus, either the 1st two companies reduced the credit to consumers, or MMP buyers had some problems with the payment for the plant's products.

It is also important to compare the turnover of receivables and working capital. If the 1 st coefficient is higher (as in this case), it means a high intensity of money flowing into the company's accounts and low financial leverage.

\subsubsection{Payables turnover- $R_{A P T}$ is defined as Revenue/Average payables}

If the necessary information is available in the numerator of this indicator, the value of the company's purchases on credit is used.

This figure should be compared with the previous one for understanding the company's financial policy. It is considered successful if the duration of accounts payable turnover is longer than the receivable. This allows the company to "use" other people's funds on credit for longer than to provide its own.

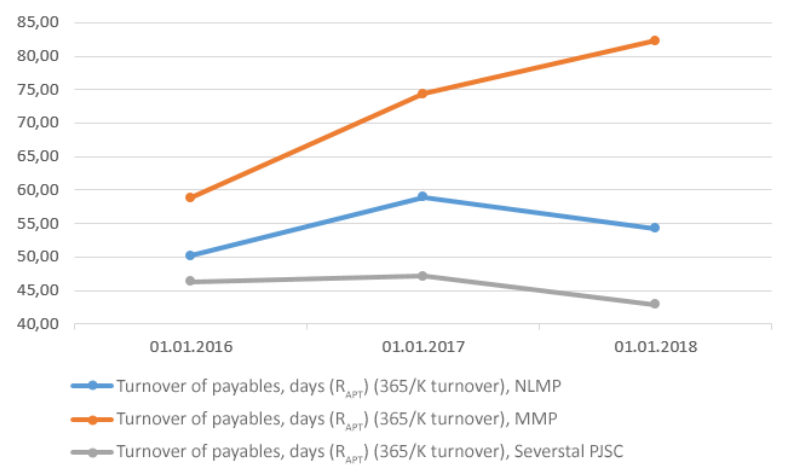

Fig. 6. Turnover of payables, days.

The graph shows that such a profitable credit policy for the company is typical for Novolipetsk and Magnitogorsk plants. They have the duration of the period of payment of bills increased by 4 and as much as 30 days (!) The growth of the latter seems to be very sharp and requires additional clarification of the reasons.
Severstal, on the contrary, accelerated its payments to creditors by 4 days.

If we compare the length of turnover of receivables and payables, in general, these companies are characterized by the following ratio: for Severstal and Novolipetsk plant the turnover of payables exceeds turnover of receivables by $15-17$ days, and for Magnitogorsk one-by 49 (at the end of the period), which undoubtedly requires clarification of the reasons.

\subsubsection{The duration of the financial cycle, which is a period of time from the payment for raw materials to the receipt of cash for the sold products (the amount of the period of turnover of stocks and receivables minus the period of turnover of payables) $-R_{w c}$}

The general rules for the characteristics of financial cycles are [1]:

- If the duration of the financial cycle is much less than the duration of the production one, then there is a typical "seller's market" in the market and a "buyer's market" in the supply market;

- The financial cycle determines the need for capital turnover, i.e. in the financing of the operating cycle, which is not covered by payables.

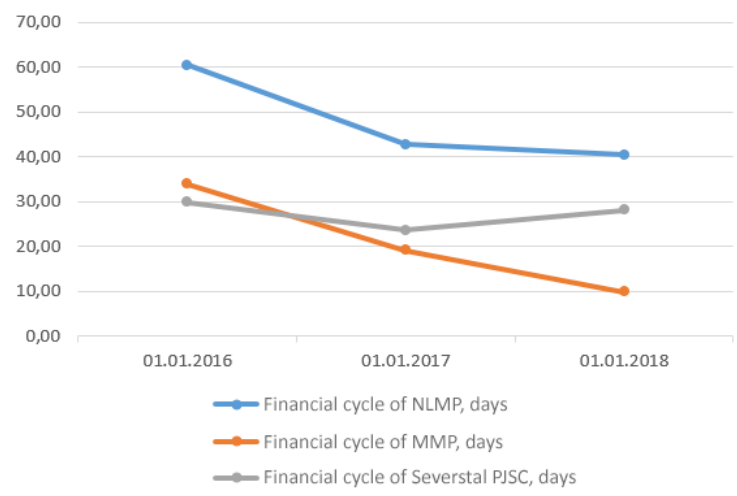

Fig. 7. Financial cycle, days.

The graph shows that the length of the financial cycle has decreased in all companies, especially in MMP. The reason for this was the increase in the period of repayment of payables (especially sharp at the MMP). Since the production cycle of all companies is much longer than the financial, before us is a picture of a typical "seller's market" dictating to buyers their terms. Today, this may be due to large-scale supply of pipes for oil and gas industries. 


\subsection{Financial sustainability indicators. They characterize the degree of use of borrowed financing: money flow management, capital structure}

\subsubsection{The security of working capital with own current assets RNWC (Current Assets - Current Passives)/Operating Assets}

For this ratio there is a recommended minimum value of $10 \%$, which means "at least $10 \%$ of own funds should be invested in operating assets" [5]. Only in this case the company can be considered financially stable. This coefficient can be negative (if current actives are less than current passives). It is an indicator of instability of the company's financial state.

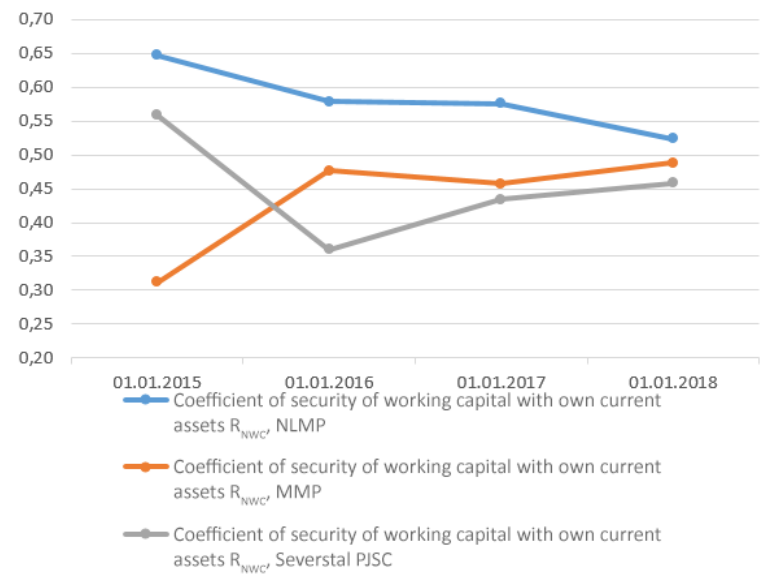

Fig. 8. Working capital.

From the figure it is clear that in 2015 the companies had a fairly large variation in fluctuations of this indicator, from 0.3 to 0.65 (with the norm being 0.1 ), which, however, was within the limits of permissible. In the latter period, the value of this ratio is in the range of $0.45-0.53$, which indicates the good financial stability of companies and possible adjustment of their policy of financing working assets.

\subsubsection{The maneuverability of equity - the $R_{M}$ ratio-} shows how much of equity is spent on working capital financing

The optimal value for this coefficient is 0.5 , but fluctuation in the range of $0.1-0.3$ is also allowed (depending on the type of activity). The ratio is defined as Own Working Capital/Own Capital.

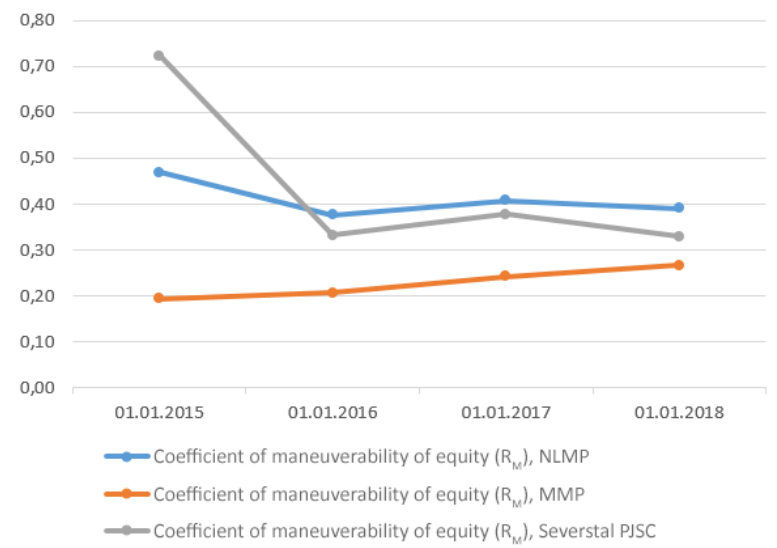

Fig. 9. Maneuverability of equity.

The value of this indicator for the companies in question is also within the acceptable limits, i.e. they can maneuver approximately $30 \%$ of their funds.

\subsubsection{The Fixed Asset Index- $R_{F A}$ is defined as Fixed Assets/Equity}

With $\mathrm{R}_{\mathrm{FA}}>1$, fixed assets are partly financed by borrowed funds; and operating assets-only from borrowed; this is considered risky;

With $\mathrm{R}_{\mathrm{FA}}<1$, fixed assets are financed by equity, suggesting a more conservative financial policy and greater (sometimes excessive) financial sustainability;

The graph shows that the value of this ratio at Magnitogorsk and Novolipetsk plants is within $1(0.9)$, while at Severstal it is 0.3 In all cases, this means that fixed assets are financed by their own equity, and at Severstal it is so with a very large margin. But since, as we know, Russian market is considered a high-risk environment $[6,7]$, this level of sustainability can be reasonable.

Thus, Severstal is the most conservative in terms of loans financial policy.

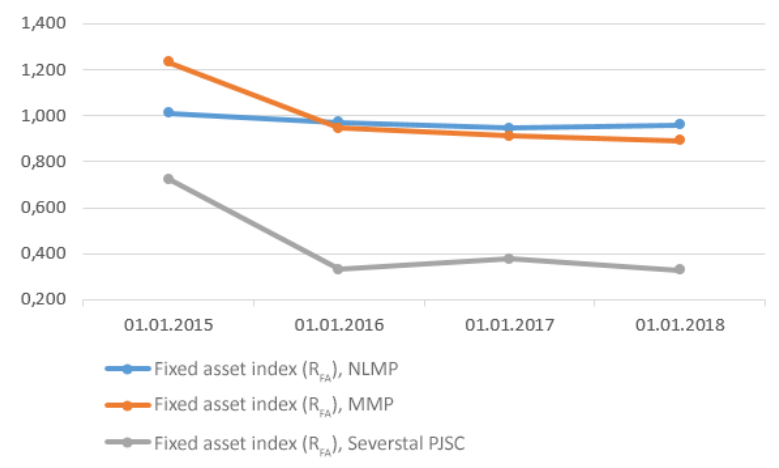

Fig. 10. Fixed Asset Index. 


\subsection{Liquidity and solvency indicators}

\subsubsection{Current liquidity ratio-ratio of current assets and passives - $C R$. Its recommended value ranges from 1 to 2}

This value indicates an adequate balance structure and the correct financial policy of the company.

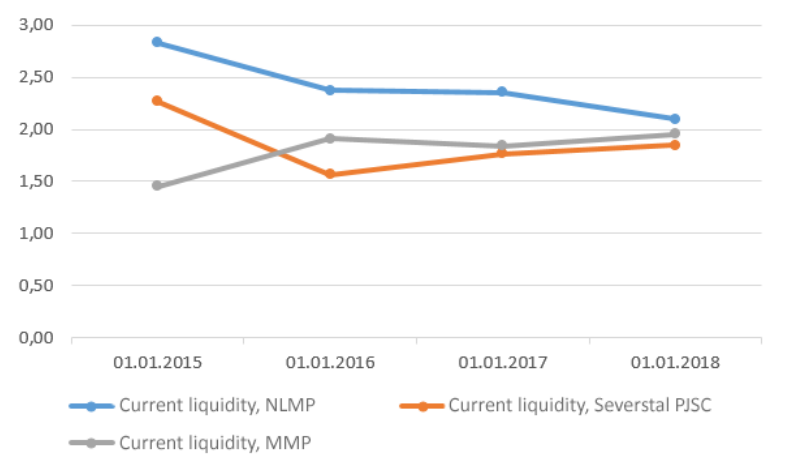

Fig. 11. Current liquidity.

All liquidity indicators, as we can see, are in the zone of maximum values and equal to 2 , and for Severstal it is even 2.1. In this way, companies can meet their financial obligations in the short term.

\subsubsection{The ratio of the debt to equity is $R_{C / A}$. It demonstrates long-term capacity to pay}

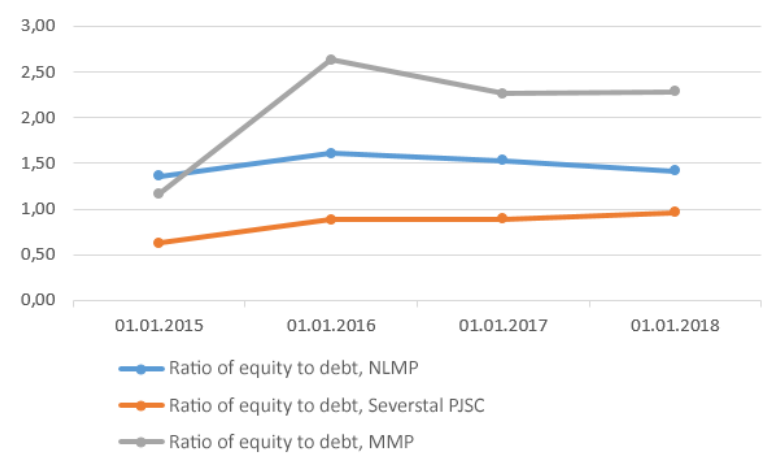

Fig. 12. Capital structure.

All coefficients are quite high, which indicates the good financial stability of companies. The lowest value is about 1-at Severstal (own funds almost equal the borrowed ones), Novolipetsk and Magnitogorsk plants' equity exceed borrowing by 1.5 - 2 times, which undoubtedly indicates a large financial "cushion" of companies, their ability to finance projects without seeking help from banks.

\section{Conclusions}

- The companies considered in the article-Severstal, Novolipetsk and Magnitogorsk plants-have good performance of business activity:

- Sufficient turnover of assets (1.1 and above); noncurrent assets (more than 1.6). In all companies there is an increase in the turnover of reserves and receivables (in times), as well as a reduction in the turnover of payables and the financial cycle of companies, which, on the one hand, indicates the optimization of financial policy, and on the other-the presence of a "seller's market" in the market of finished products;

- The companies considered can be called financially stable in terms of a whole group of financial indicators: they have more than $50 \%$ of their own working capital invested in working assets (with the norm at $10 \%$ ), they can maneuver about $30 \%$ of their funds (equity invested in working assets). Fixed assets of companies are financed by their own funds;

- The companies are also financially stable in the short term: their current liquidity is at the upper limit of the norm-2 and above. In the long term, companies are also solvent, judging by the capital structure: equity exceeds borrowing by 1.5-2 times, i.e. companies can finance some of their projects independently without resorting to loans.

\section{References}

1.V.G. Cogdenko, M.V. Melnik, Management of company value: textbook. M.: Unity, 88 (2014)

2.https://www.severstal.com/files/23850/Annual_rep ort_2018_RUS.pdf (2019)

3.http://www.mmk.ru/upload/iblock/8c6/MMK_IFR S\%20208-FZ_2018.pdf(2019)

4. https://nlmk.com/ru/ir/reporting-center/annualreports/ (2019)

5.A.S. Bobyleva, Financial management: problems and solutions. Part 1 M.: Jright, Ch 2, 110 (2019)

6. Valery Yanovskiy, Lyubov Shamina, Alexey Shmatko, Adaptability as a tool for managing an enterprise in a turbulent external environment // Advanced Science Letters 24 6323-6325 ISSN: 19366612 EISSN: 1936-7317 DOI: 10.1166/ASL.2018.13043 (2018)

7.A.O. Nedosekin, A.D. Shmatko, Z.I. Abdoulaeva, Fuzzy Preliminary Evaluation of Industrial Risks, Proceedings of XX IEEE International Conference on Soft Computing and Measurements (SCM) DOI: 10.1109/SCM.2017.7970711 (2017)

8.E.P. Ilyenko; E.I. Rejshahrit, A.D. Shmatko, Qualimetric Model as a Tool for Identifying the Cost of Activities on Occupational Safety in the Coal Enterprise Proceedings of XX IEEE International Conference on Soft Computing and Measurements (SCM) DOI: 10.1109/SCM.2017.7970675 (2017) 